\title{
肉用種鵎育成用飼料に関する研究
}

\section{VI. 高エネルギー扔よび隔日給与の効果について}

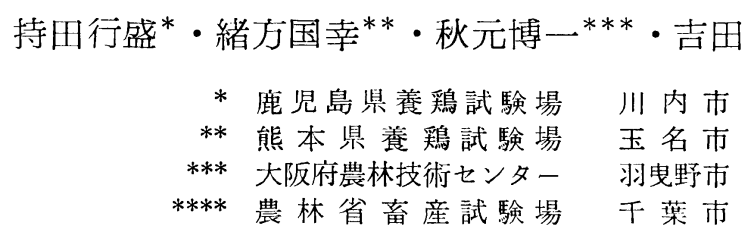

肉用種鶏は産肉性の高いブロイラー生産のため, 発有 の速い体重の大きいものに品種改良が行なわれてきた が，体重が大きくなれば飼料拱取量が多く，発育を速く

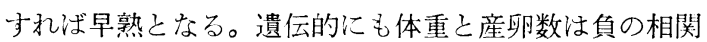
があり，体重が大きくなること核産卵能力が低下するこ とになり，ブロイラー素ひな生産の低下をきたす結果と なる。

そこで本来，体重が大きいという遺伝的能力を失なわ ないように飼養管理によって, 肉用種鶏の経済性を高好 る方法として 飼料の制限給与法について研究されてい る。特に有成飼料の制限給与は, 飼料の節約とともに, 発育を抑制して性成熟を遅らせ，産卵初期の卵重を高 め, 産卵率, 特にピークの期間を延長し, 種卵採取個数 が多く，あわせて生俘率，ふ化率の向上に役立つといわ れている 1 。著者らは，肉用種鷄育成飼料に関する研究 を農林省畜産試駼場と各府紧との協同研究で実施してお り，その第 1 報では21)，ふ寸まによる低エネルギー飼料 の給与および 7 日のうち 1 日だけ飼料を与えない給与法 の影響について報告している。低エネルギー飼料を給与 すると飼料の㠌取量が多くなり，7日のうち 1 日飼料を 与光ない給与法では飼料の搷取量に垶はなく，期待した

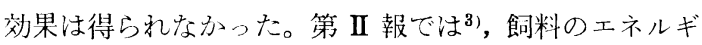
一や粗蛋白質会量を極端に高低にした飼料ならびに，1 日打き飼料の給与法について報告し，育成期に高エネル ギー飼料打よび 1 日抢き飼料を給与しても産卵期に大き な影響はみられず，䏍成費を節約する可能性があること を示唆した。第 III 報では4高エネルギー飼料では，過肥 となって産卵に悪影響をおよぼすようなことは認められ なかったが, 育成費の節約, 産卵成績の向上は期待でき ざ，飼料組成を大幅に変化させる必要性を恐めた。第 IV 報では5', 3 日のうち 1 日および 2 日のうち 1 日飼料老与 えない給与法について報告したが，鵎に強いストレスと はならず，光しろ生存率注高く，産卵成績法向上する傾

昭和 46 年 7 月 20 日受付
向がみられた。これらの一連の研究結果から, 高エネル ギー飼料抢よび隔日給与の効果について，さらに検討与 る価值があることが示唆された。そこで㕕成期における 高エネルギー飼料の給与および隔山給与の効果について 検討する実験を行なったので，その成果を報告する。実 験は大阪府農林技術センター (以下大阪), 熊本県養䳕 試験場 (以下熊本), 鹿児島罧湌䳕試験場 (以下鹿児島) に挄て実施した。

\section{実験材料および方法}

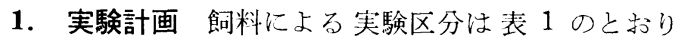
で，高エネルギー飼料および隔日給与の影響を検討する ため, 各場ごとに 8 試験区を設け，これを 2 分し，育成 期に高エネルギー飼料を給与する群と対照飼料を給与す る群に分け,さらに各群を 2 区ずつに細分して, 最初の 2 区には飼料を連日給与し, 他の 2 区には隔日に給与し た。産卵期は同一組成の産卵用飼料を, 連日給与区には 引き続き連日給与し，隔日給与区には引き続き隔日に給 与した。したがって，実験計画は，各場をブロックとし， 各ブロックごとに, 育成用飼料のエネルギー水準 2 水 準, 育成, 産卵期を通じて飼料の給与を連日沶よび隔日 の 2 水準として, 各 2 反復を設けた, 反復のある $2 \times 2$ 型 2 元配置法をわりあてた乱塊法実験計画となっている。 実験注 8 週齢から 24 週齢までの育成期と, それ以降の 60 週龄までの産卵期とに分けて実験した。

表 1. 飼料による实験区分

\begin{tabular}{|c|c|c|c|c|c|}
\hline \multirow{2}{*}{ 試験区. } & \multicolumn{2}{|c|}{$\begin{array}{l}\text { 育成 用飼料 } \\
(8 \sim 24 \text { 齢) }\end{array}$} & \multicolumn{3}{|c|}{ 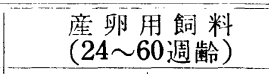 } \\
\hline & $\mathrm{CP}-\mathrm{TDN}$ & 給 与 法 & $\mathrm{CP}-\mathrm{TDN}$ & 給 与 & - 法 \\
\hline 1 & $16-66 \%$ & 連日 & $18-66 \%$ & 連 & 日 \\
\hline 2 & $16-66$ & 隔 日 & $18-66$ & 隔 & 日 \\
\hline 3 & $10-76$ & 連 日 & $18-66$ & 連 & 日 \\
\hline 4 & $10-76$ & 隔 日 & $18-66$ & 隔 & 日 \\
\hline
\end{tabular}


2. 供試鷄および 飼養法 供試鵎は 1968 年春季ふ心化 の白色ロック種 $\mathrm{A}$ 系統㧍よびJ系統を用いた。各場とも 8 週龄の実験開始まで，それぞれの場の慣行法で育成し たものを供試し，大阪は各区 15 羽の計 120 羽，熊本は各 区 20 羽の計 160 羽，鹿児島注各区 25 羽の計 200 羽で実 験を開始した。飼養はすべて平飼いとして，产卵期法同 一鷄種雄を各区 2 羽亦て配した。点灯注熊本，鹿児島で 泣産卵 $50 \%$ 以降照明が 15 時間になるように点灯した が，大阪注実施しなかった。

3. 供試飼料 農林省畜産試験場で配合表を作製し, 表 2 , 供試飼料の組成

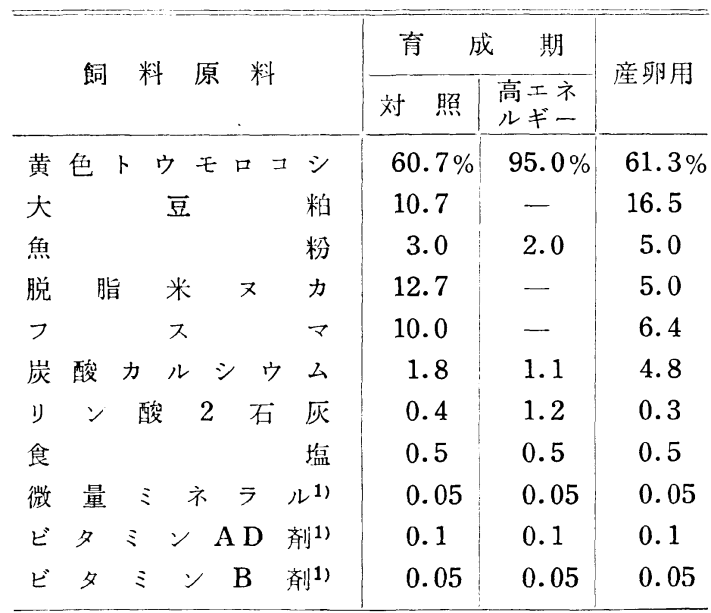

1）交献 2 の表 3 , 脚注 1,2 および 3 参照.

飼料会社に一招依頼製造したもので，その組成を䘚 2 に 示した。

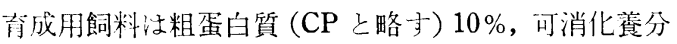
総量 (TDN 之略す) $76 \%$ の低蛋白質高エネルギー飼料 之 CP $16 \%$, TDN $66 \%$ の刘照飼料の 2 種類で, これを 8 淍龄尔ら 24 週齢まで給与した。产邪用飼料は CP 18 $\%$, TDN $66 \%$ のもので, 供試鶏の 24 週齢以降に給与乙 た。飼料の $\mathrm{CP}$, TDN 含量流いずれも計算値である。

4. 測定項目 育成期中の増体量, 飼料摂取量を測定 し, そ机によって, 飼料要求率を求めた。初産日龄およ び初産卵重泣産卵 $50 \%$ に達した日龄および卵重によっ て求內た。産卵期成緽の産卵率, 卵重, 飼料恸取量注 4 涸間を 1 期とする 9 期に区分して各期ごとに測定した。 第 1 期 (24〜28 週齢) の成緽は, 産卵成績不揃のた成 絴の分散分析に亦たり除外した。44週龄体重, 生存率,

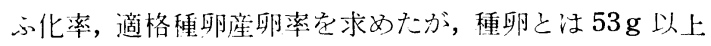
の正常卵汇上, て求河, 交化率法熊本, 鹿児島汇ついて の及 3 回測定した。経済性洼種卵 1 個生産寺るに要した 飼料費により次式で算出した。
育成期飼料搝取量 $\times$ 単䧈 + 経済性 $=$ 産卵期飼料摂取量 $\times$ 単価 種 卵数

成 績

青成期の成積扩よび産卵期の生存率, 飼料摄取量, 体 重, 初産日齢, 初産卵重については, 飼料エネルギーと 飼料給与法の 2 因子抄よびブロック因子につき $3 \times 2 \times 2$

表 3. 笑験成績の要約

\begin{tabular}{|c|c|c|c|c|}
\hline & 対 & 照 & 高工 & . \\
\hline & 連日 & 䧣白 & 連日 & 隔日 \\
\hline 成期（8～24週齢） & & & & \\
\hline 育 成 & 98.2 & 98.2 & 98.5 & 100.0 \\
\hline 24 週齢時体重 $\mathrm{kg}$ & 2.98 & 2.71 & 2.91 & 2. 19 \\
\hline 増 体 量 $\mathrm{kg}$ & 1.77 & 1.50 & 1.72 & 0.99 \\
\hline 飼料摂取量 & 12.6 & 12.0 & 11.1 & 9 \\
\hline 飼 料 要 求 率 & 7.1 & & 5 & \\
\hline 卵期（24～60週歯命） & & & & \\
\hline 初産 日 齢 日 & 175 & 3 & 86 & \\
\hline 初産 卵重 $\mathrm{g}$ & 49.4 & 49.7 & 51.7 & 54.5 \\
\hline $\begin{array}{l}\text { 飼 料 摂 取 量 } \\
\text { ( } 1 \text { 日 } 1 \text { 羽平均) }\end{array}$ & 158.1 & 142.7 & 142.2 & 138.2 \\
\hline 生存率 \% & 90.5 & 88.7 & 94.3 & 91.0 \\
\hline 44 週齢 体重 $\mathrm{kg}$ & 3.62 & 3.34 & 3.40 & 25 \\
\hline 経＼cjkstart済 & 15.4 & & 15.0 & \\
\hline 率 \% & 55.1 & 56.3 & 53.2 & 53.2 \\
\hline 適格種卵座卵率 & 51.8 & 52.7 & 49.4 & 49.8 \\
\hline 卵 & 62.0 & 60.6 & 61.3 & 60.3 \\
\hline 飼料要求率 & 5.25 & 4.83 & 4.86 & 5.33 \\
\hline 刘有的化率 & 83.7 & 81.0 & 82.2 & 84.9 \\
\hline
\end{tabular}

型 2 反復要因実験として, 分散分析した。また, 产卵率, 適格種卵産卵率, 飼料要求率, 卵重汁 $3 \times 2 \times 2$ 型 2 反復 の実験を 1 次因子とし, 測定時期を 2 次因子とみなし て，分割区法を適用して解析した。尔化率については 2 ブロックの $2 \times 2 \times 2$ 型 2 反復の 1 次試験に, 3 回の方化 試験時期を 2 次因子とみなして分割区法を適用して分散 分析を行なった。この分散分析には, 農林研究計算セン ターの TOSBAC 3400 を用いた。分散分析結果注記述 を簡単にするために，誤差分散とその目由度のみを数值 で示し，それ以外注有意上判断できるか否かを記号で小 して表4にまとめた。

\section{I. 育成期間 (8〜24 週齡時) の成績}

表 3 に示したように，有成率では $98.2 〜 100.0 \%$ で いずれも良い成績を示し，飼料のエネルギーおよび給与 法により差があるとはいえなかった。飼料の掑取量は飼 料のエネルギー条件により $1 \%$ 水準で, 飼料の給与条件 により $5 \%$ 水準で有意差がみられた。与交わち，刘照飼 
料の平均掑取量が $12.3 \mathrm{~kg}$ であったのに対し, 高エネル ギー飼料では $10.0 \mathrm{~kg}$ で約 $81.1 \%$ にすぎなかった。ま た，連日給与去ると，平均 $11.85 \mathrm{~kg}$ 食べたのに対し， 隔口給与では $10.45 \mathrm{~kg}$ で，約 $11.8 \%$ 抑制された。増体 量は対照飼料では，罊日給与で， $1.5 \mathrm{~kg}$ で， $15.1 \%$ 抑 制されているが，高エネルギ一飼料では，隔日給与で， $0.99 \mathrm{~kg}$ で, $42.4 \%$ 抑制され，飼料エネルギーによっ て，隔目給与の体重抑制效果に差が琶められた。飼料酒 求率流照飼料では, 缡日給与で, 8.0 で, 0.9 少り, 高 エネルギー飼料では，隔日給与で，9.0で，1.9少り，飼 料給与法によって差が㤎められた。

\section{II. 初産日齡と初産卵重におよぼす㕕成飼料の影響}

表4に示したように, 初産日齢は飼料エネルギーと飼 料給与法に，それぞれ $5 \%$ 水準で有意差が琹められた。 高エネルギー飼料の給与により，対照飼料の給与より米 均 21 日小くれまた，隔日給与は連日給与より平均 19 日おくれた。初産卵重は高エネルギー飼料を給与すると 対照飼料より， $3.5 \mathrm{~g}$ 重く，5\% 水準で有意差が梁めら れたが，飼料給与法による差は涊められなかった。

\section{III. 産卵期間 $(24 \sim 60$ 週齡) の成績}

第 1 期を除く産卵率についてみ扎ば，首成期に高エネ ルギー飼料を給与すると刘照飼料給与より $2.5 \%$ 劣り, $5 \%$ 水準で有意差が涩められたが，隔日給与と連日給与. との間に統計的有意差は想められなかった。なた，産卵 期に饲料を隔日給与しても産卵率に悪影響は夕られなか った。冬時期ごとに倛試した䳕群の総平均值䒚四示する
と図1のようになり，座畉率は初应後しだいに上帠し， 第 5 期 (40〜44 週龄) に産卵率が低下しているが，これ

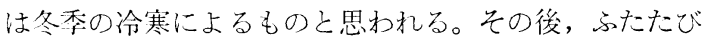
上鼠し，第 8 期（52〜56 週龄）にピークに達している。 第 1 期を除く適格種卵産卵率は飼料エネルギーの残效沶 よび飼料給与法に有意差涊められなかった。平均卵重 は飼料給与法の差により $1 \%$ 水準で有意差が涩められ， 隔日給与区注連日給与区より $1.2 \mathrm{~g}$ 軽かった。1日1羽 当たりの飼料摂取量は 飼料エネルギーと飼料給与法に, $1 \%$ 水準で有意差が拝められ，育成期に高エネルギ一飼 料を給与した区注対照飼料区に比し， $8 \mathrm{~g}$ 少なく，陑日 飼料区は逨日給与区に比し, $12 \mathrm{~g}$ 少なかった。飼料要求 率には飼料エネルギーの残効および飼料給与汢による差 は有意ではなかった。44 週歯体重には飼料のエネルギー の残効は恋められなかったが，陑目給与区は連日給与区 に比し， $0.2 \mathrm{~kg}$ 小さく，5\% 水準で有意差が羿められ た。生存率注飼料のエネルギーおよび飼料給きj法の差に 有意差は涊めら机なかった。有精卵のふ化率も充成用飼 料のエネルギーおよび飼料給与法の差に有意差は涩めら れなかった。種卵 1 個当たりの飼料費は奇成期に高エネ ルギー飼料を給与して育成すると種卵 1 個当り 14.4 円 で，対照飼料区に比し，0.3 円安かったが, 統計的有意差 注認められなかった。また, 充成斯, 産卵期を通じて飼 料を隔日給与すると連日給与区に比し, 種卵 1 個当り 1.3 円安く, 統計的にも $5 \%$ 水準で有意差が認奶られた。 したがって，育成期に高エネルギー飼料を隔日給与寺る

表 4 . 分散 分

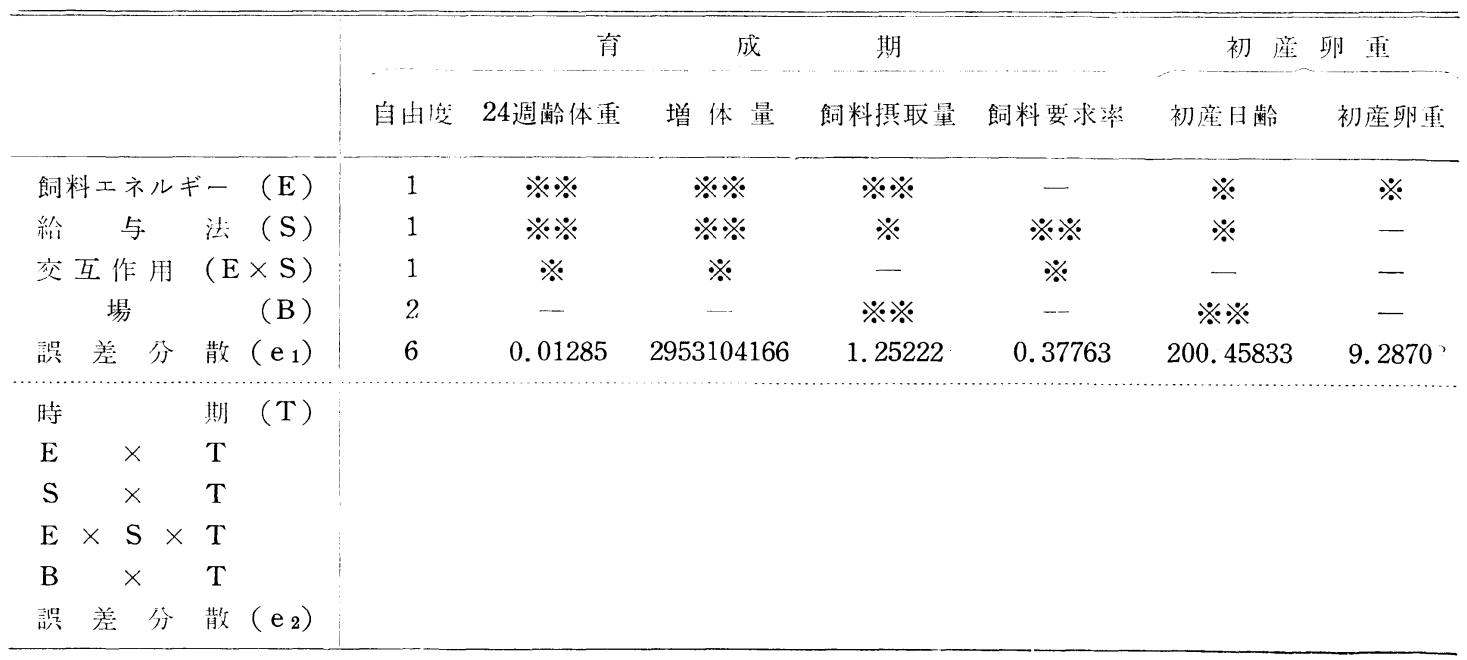

1), 1') : $\mathrm{E} \times \mathrm{B}, \mathrm{S} \times \mathrm{B}, \mathrm{E} \times \mathrm{S} \times \mathrm{B}$, プールしたもの

2), $2^{\prime}$ ): $\mathrm{T} \times \mathrm{E} \times \mathrm{B}, \mathrm{T} \times \mathrm{S} \times \mathrm{B}, \mathrm{T} \times \mathrm{E} \times \mathrm{S} \times \mathrm{B}$ プールしたもの

3 ), ※※: 危険率 $1 \%$ で有意

※：危険率 $5 \%$ で有意 


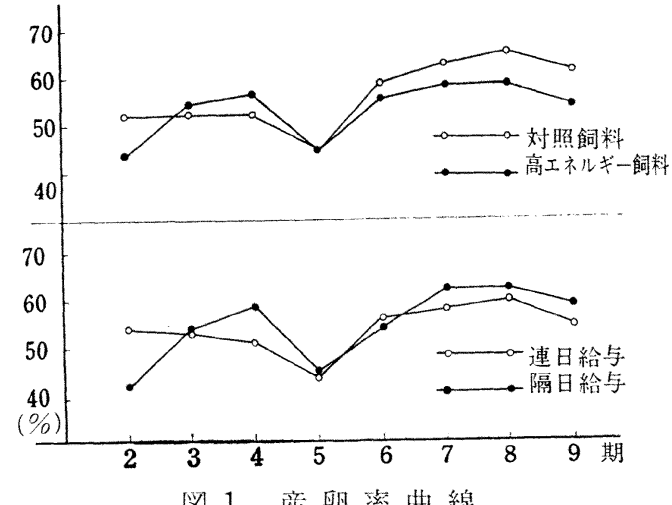

図1. 産卵率曲線

と刘照飼料定連日給与寻るのに比し，種卵 1 個当引 1.6 円安く生制できた。

\section{考察}

本笑験は，第 II 報の探索実験 $605^{32}$ 莸規模拡大したも ので，成緽の傾向もよく一致している。育成期の高エネ ルギー飼料給与は, 飼料摂取量, 24 週菊令体重はそれぞれ $81.1 \%$ と $89.4 \%$ に抑制されている。また，隔日給与は それぞれ $88.2 \%$ と $83.9 \%$ として抑制されているが，そ の効果は産卵期には残存していない。したがって，この 锺の高エネルギー，低蛋白質飼料を給与することによ り，過肥その他生理的異常は抢こらないと判断される。 青山( ${ }^{6}$ によると産卵率向上のためては 24 週齿体重を $70 \%$ 以下に制限卞るとよいと報告している。しかし，本
実験での高エネルギー 飼料の給与および隔日給与とも こ，この点で注抑制は不十分と考えられる。両者を併用 した高エネルギー飼料を隔日給与することにより，73.4 \%に制限できた。この高エネルギ一飼料は低蛋白質と なっており，これでけでは抑制は不十分で，隔日給与と 組合せ全体として強く抑制することができたもので，こ

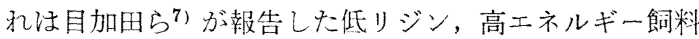
として，提取量を抑制し，低リジンの影響をより強く作 用させようという報告と共通している。充成期に高エ ネルギー飼料と隔日給与の組合せでは，産卵率は $53.2 \%$ で, 対照飼料の連日給与区に比し，1.9\%低かったが，産 卵成緽に悪影響はみられず，飼料費は最も少なくなって いる。逳成期，産卵期を通じて飼養標準にほぼ適合して いる飼料を隔日給与する力j法では, 24 週龄体重は対照区 の $90.9 \%$ に抑制され，44 週龄時体重でも $92.3 \%$ で,初産 汇8 日遅孔るが適格種卵産卵率は $0.9 \%$ 高く, 飼料摄取 量は育成期 $95.2 \%$ ，産卵期 $90.3 \%$ に抑制され，乙たが って種卵 1 個当りの飼料費は平均 1.4 归少なくなって 晾り，生理的な異常は全く認められなかった。なお，図 1 から明らかなように，この給与法では $7 ， 8 ， 9$ 期の後 半に産卵率が上廻り，さらに試験期間を延長すると産 卵率の差, ひいては飼料費の差は拡大寸るものと思和机 る。育成期, 産卵期通じての隔日給与は実用化が十分 考えられる。

育成期の高エネルギー飼料, おょび飼料の隔日給与法 について，第II 第IV報で報告したように，飼料費の節 約，体重の抑制が可能でかなり有效であることが示㖫さ

析 0 結 果

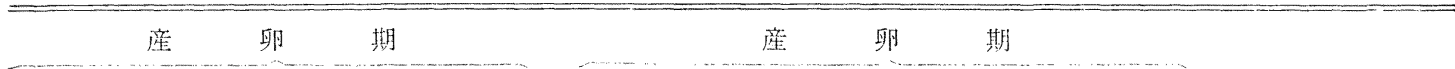

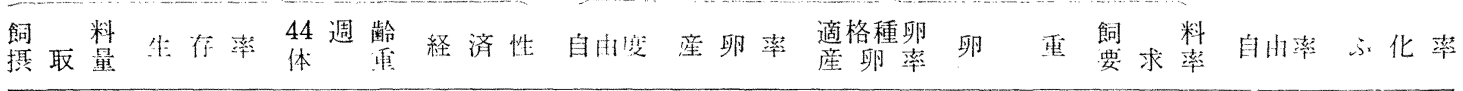

\begin{tabular}{|c|c|c|c|c|c|c|c|c|c|c|}
\hline$※ ※$ & - & - & - & 1 & $※$ & - & - & - & 1 & - \\
\hline$※ ※$ & - & $※$ & $※$ & 1 & - & - & $※ ※$ & - & 1 & - \\
\hline$※$ & - & - & - & 1 & - & - & - & - & 1 & - \\
\hline$※ ※$ & - & $※ ※$ & $※ ※$ & 2 & $※ \dddot{*}$ & $※ ※$ & $※ ※$ & $※ ※$ & 1 & - \\
\hline \multirow[t]{7}{*}{27.80847} & 91.81944 & 0.02385 & 1. 37653 & 6 & 50.87120 & 82.22659 & 4.4740 & 2.80374 & 3 & 44.54354 \\
\hline & & & & 7 & $※ ※$ & $※ ※$ & $※ ※$ & $※ ※$ & 2 & - \\
\hline & & & & 7 & $※$ & - & - & $※$ & 2 & - \\
\hline & & & & 7 & $※ \%$ & $※$ & - & - & 2 & - \\
\hline & & & & 7 & - & - & - & - & 2 & - \\
\hline & & & & 14 & $※ ※$ & $※ ※$ & $※ ※$ & $※ ※$ & $?$ & - \\
\hline & & & & 42 & 56.36375 & 66.28870 & 0.87281 & 2.63758 & 6 & 26.80927 \\
\hline
\end{tabular}


れた。本実験では，CP 10\%，TDN 76\% の低蛋白質高 エネルギー飼料および飼料の隔日給与法で育成し, 産卵 期には CP 16\%, TDN $66 \%$ の飼料を育成期に引き続き， 連日給与と隔日給与とに区分し，飼養したが，育成期に 高エネルギー飼料を給与しても過肥になったり，飼料を 隔日給与としても鷄に異常に強いストレスを与えること はなく, 産卵成績にも悪影響はなかった。特に育成期に 高エネルギー飼料と隔日給与を組合せると，体重を抑制 乙, 飼料掑取量が少なく, 育成率, ふ化率も向上し, 産 卵成績に悪影響はみられず, 飼料費の節減から種卵生産 費索低下させ，経済的にもかなり有效で，実用性がある もの上思われる。

\section{要}

約

肉用種鶏育成飼料に関する研究を農林省畜産試験場と 各祡養鶏試験場との協同研究としてとりあげているが， その第VI報として，第II 報の実験 605 の探索実験を規模 拡大し，高エネルギ一飼料の効果扩よび飼料の隔日給与 の效果について検討した。

実験は，1968 年 4 月ふ化の白色ロック種A系統および J 系統 480 羽を用い，育成期（8２4 週齢）およびその 後の産卵期 $(24 \sim 60$ 週龄) 飞わたって, 大阪, 熊本およ び鹿児島の各養鵴試験場で実施した。その結果を要約寸 ると次のと㧍りである。

1. 育成期に高エネルギー飼料を給与すると対照飼料 区に比し，飼料拱取量は $81.3 \%, 24$ 週齢時体重は 88.1 \%であった。初産日龄㳉 21 日おく扎たが, 産卵成績に 悪影響はなかった。
2. 肖成期に 飼料学隔日 給与すると連日給与区に比 し，飼料搷取量は. $88.2 \%, 24$ 週龄時体重は $83.2 \%$ に抑 制され，初産日齢は 18 日おくれたが，その効果は産卵 期には残存せず，悪影響はみられなかっだ。

3. 育成期, 産卵期を通じて飼料を隔日給与すると連 日給与区に比し，飼料撰取量は $90.1 \%, 24$ 週齢時体重 は $90.9 \%$ に抑制された。初産日齢は 17 日おくれ，44 週 齢 $92.3 \%$ で, 生存率, 産卵率, 飼料要求率, ふ化等に大 差法々られず，種卵 1 個当りの飼料費では 1.3 円安か。 た。

4. 㕕成期に高エネルギー飼料と隔日給与を組合せる と対照飼料の連日給与区に比し，飼料摂取量は $69.0 \%$, 24 週齢時体重は $55.9 \%$ に抑制され，高エネルギー飼料 の給与による過肥や, 隔日給与による生理的異常法おこ らず，産卵成績に悪影響はみとめられ尔かっだ。

\section{引用 文 献}

1) 吉田 実：家禽学会誌 8, 131，1971.

2）飯野雅夫・緒方国幸・藤原正美・吉田 実：同上 5, 72, 1968.

3）吉田 実・星井 博・森本 宏：同上 6, 89, 1969.

4）緒方国幸・吉村 幸・秋元博一・野中 進・吉田 実：同上 6, 132，1969.

5）飯野雅夫・水谷一之・目加田博行・榐 正美・緒 方国幸・吉田 実：同上 6, 179, 1969.

6）青山 定・松島 正洋・井上正義・船越直方・阔 義美・嚴 正美：同上 7, 85, 1970.

7）目加田博行 - 大堀保也 - 海老沢昭二 ・金原一吉 吉田 実：同上 7, 118，1970 


\title{
Studies on the Grower Diet for Meat-type Pullet
}

\author{
VI. Effect of Feeding High Energy Grower Diets and of \\ Alternative Day Feeding
}

\section{Yukimori Mochida*, Kuniyuki OGata**, Hakuichi AкIмото***, Minoru Yoshida**** \\ * Kagoshima Prefectural Poultry Experiment Station, Sendai-shi \\ ** Kumamoto Prefectural Poultry Experiment Station, Tamana-shi \\ *** Osaka Agricultural Research Center, Habikino-shi \\ **** National Institute of Animal Industry, Chiba-shi}

Collaborative experiments were carried out in three Prefectural Poultry Experiment Stations in Kagoshima, Kumamoto, and Osaka in 1968 using total 480 White Plymouth Rock $\mathrm{A}$ and $\mathrm{J}$ line pullets to obtain a method of restricted feeding program for meattype growing pullets.

The experiment was performed to confirmed the findings obtained in the preliminary experiment reported in the second paper on this subject.

Control grower diet contained $16 \%$ of crude protein $(\mathrm{CP})$ and $66 \%$ of total digestible nutrients (TDN) and high energy grower contained $10 \%$ of $\mathrm{CP}$ and $76 \%$ of TDN.

The grower diet was fed two duplicated lots of pullets from 8 -to 24 weeks of age.

After 24 weeks of age, all the pullets were fed the layer diet of $18 \% \mathrm{CP}$ and $66 \%$ TDN, and the experiment was separated two sections throughout 8 -to 60 week-old, one of duplicated lots was fed every day, the other was alternative day feeding.

1) Pullets fed high energy diet in growing periods resulted in $18.7 \%$ less feed intake and $11.9 \%$ less body weight at 24 week-old than those of the control pullets fed every day.

Maturity was delayed at 21 days, while little difference in laying performance was observed.

2) Pullets on alternative day feeding in growing periods resulted in $11.8 \%$ less feed intake and $16.8 \%$ less body weight at 24 week-old than those of the pullets fed every day. Maturity was delayed at 18 days. Little difference in laying periods was observed.

3) Pullets on alternative day feeding throughout growing and laying period resulted in $9.7 \%$ less feed intake, $9.1 \%$ less body weight at 24 week-old and $7.7 \%$ less at 44 week-old than those of the pullets fed every day. Maturity was delayed at 17 days. Little difference was observed between the 2 groups in viability, egg production, feed conversiond and hatchability at laying periods. This alternative day feeding was expected to cut down the feed cost per hatchable egg due to lower feed intake in growing and laying period.

4) Pullets fed high energy diet an alternative day feeding at growing period resulted in $29.4 \%$ less feed intake $44.1 \%$ with less body weight at 24 week-old than those of the pullets fed control diet.

The last method was most expected to cut down the feed cost per hatchable egg due to lower feed intake and little difference in laying period.

(Japan. Poultry Sci., 9, 40 45 1972) 